\title{
The impact of Sana'a solid waste on the quality of groundwater in Yemen
}

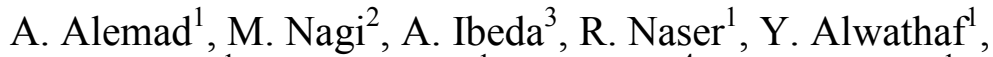 \\ O. Elrhaouat $^{1}$, K. Elkharrim ${ }^{1}$, A. Babaqi ${ }^{4} \&$ D. Belghyti ${ }^{1}$ \\ ${ }^{1}$ University Ibn Tofail, Kenitra, Morocco \\ ${ }^{2}$ Laboratory Sana'a Water and Sanitation Local Corporation, Yemen \\ ${ }^{3}$ Organization of Development, Libya \\ ${ }^{4}$ Laboratories of Earth and Environment, Sana'a University, Yemen
}

\begin{abstract}
The main objective of this research is to study the quality of water in terms of a physico-chemical analysis of groundwater and the impact of solid waste on the quality of drinking water for residents of the study area, Sana'a Basin. The present investigation was carried out to analyze water samples from Sana'a Basin during the winter season of 2010. Parameters such as $\mathrm{pH}$, conductivity, TDS, alkalinity, sodium, potassium, calcium, magnesium, nitrate, sulfates, phosphates and chloride as well as heavy metals such as $\mathrm{Cd}, \mathrm{Cr}, \mathrm{Cu}, \mathrm{Zn}, \mathrm{Fe}, \mathrm{F}$, $\mathrm{Pb}, \mathrm{Ni}, \mathrm{Mn}$, and $\mathrm{Zn}$ have been studied. The physico-chemical analysis showed that the selected major ions of the analyzed samples were within the limits of the World Health Organization (WHO) Guidelines and Yemen Standard. The analysis showed that there is a sort of groundwater pollution with some of the selected trace elements. It was found that three samples out of twelve were polluted with chromium; two were polluted with fluoride, two with iron and three with nickel. It was found also that lead in eight samples out of twelve have either slightly higher concentrations than the WHO Guidelines or the permissible maximum level of it. However, on the other hand, according to Yemen Standards limits, $\mathrm{Pb}$ concentrations in all samples were within the limits. We can conclude that the groundwater of this region is unsuitable for drinking or human use because of increases in heavy metals according to the WHO Guidelines and the standard specifications of Yemen.

Keywords: groundwater, quality, physico-chemical, Al-Azraqin, Sana'a, Yemen.
\end{abstract}




\section{Introduction}

Yemen is burdened with low human and economic development, serious environmental challenges, and a high degree of vulnerability to current climatic variability and future climate change. Yemen's major environmental problem is water scarcity, which is prone to exacerbation under climate change. According to the country's First National Communications, temperature across the country is expected to rise, while precipitation is expected to decrease, leading to increased pressures on the country's delicate water resources (Noaman [1]).

Water quality means different things to different persons because of the various perspectives from which they approach it. Generally, it refers to characteristics of attributes of water, good or bad, that relate to its acceptability for certain purposes or uses [2].

Water pollution has many sources and characteristics. Humans and other organisms produce bodily wastes which enter rivers, lakes, oceans and other surface waters; in high concentrations. These wastes result in bacterial contamination and excessive nutrient loading (eutrophication). Industries discharge a variety of compounds such as heavy metals.

The sources of water pollution can be categorized as being a point source and non-point source of pollution. Point source pollution occurs when the polluting substance is emitted directly into the water way. The non-point source of pollution occurs when there is runoff of pollutants into a water way. One of the important sources of groundwater pollution is the land disposal of solid wastes. Landfill may be defined as any land area serving as a depositary of urban, or municipal, solid waste. The problem of pollution from landfills is greatest where high rainfall and shallow water tables occur. Important pollutants frequently found in leachate include $\mathrm{BOD}, \mathrm{COD}$, iron, manganese, chloride, nitrate, hardness, and trace elements. Hardness, alkalinity, and total dissolved solids are often increased, while generation of gases, such as methane, carbon dioxide, ammonia, and hydrogen sulfide, are further by-products of landfills.

Yemen is a water-scarce country. It is situated in a semi-arid region with very limited water resources. Therefore, high population growth rates, accelerated urbanization, and rapid economic development have increased the pressure on water resources, and have led to a continuous process of degradation of these resources endangering the long-term water sustainability. The annual per capita share of renewable water resources does not exceed 125 cubic meters (the water poverty is 1000 cubic meters) (ESCWA [3]). Water shortages in Yemen are associated with poor water quality, particularly in the areas that are hosting heavy economic activities. The situation in Sana'a city is extremely serious because more than 2 million people live in it, as a result of centralization and internal immigration. Accordingly, some areas of Sana'a basin experience water quality problem, especially the northern part of Sana'a city, i.e. Arhab and Bani Al-Harith areas around the wastewater treatment plant.

There are currently major challenges associated with the unsustainable management of water quality of the non-conventional sources in Yemen. There is no doubt that the main source of water pollution comes from domestic, 
industrial and agricultural activities. Generally solid waste disposal sites in Yemen are not selected on scientific bases, and the construction of the landfills is not according to standards. Al-Azraqin in Sana'a city is an obvious example, which forms a major problem that may cause water quality deterioration especially for groundwater, because this site is located on an area characterized by intense geological structures and vulnerable aquifers.

The objectives of this study are to conduct a groundwater risk assessment in the vicinity of the only existing sanitary landfill of Sana'a City, also, to predict potential contamination of groundwater resources by the landfill's leachates. Accordingly, these impacts are going to be linked with the socioeconomic, environmental and institutional aspects, in the framework of IWRM concepts.

There are no collectors for this leachate since the landfill has not been designed on scientific bases, and the construction of the landfill is not according to the universal standards. Therefore, the risk of leachate seepage into the ground is expected to be present. Another reason is that contamination by leachate poses a great threat to groundwater resources because leachates contain multiple pollutants which might not be easy to remove or treat.

\section{Material and methods studies}

\subsection{Geographic area}

Sana'a City, the capital of Yemen, is situated at the southern part of Sana'a Basin (fig. 1). During the past three decades Sana'a City has grown to be the largest urban center in the country. Rapid urbanization has raised the population of the city to about 2 million. Urbanization is mostly in the form of new residential areas.

Al-Azraqin (the study area) is located to the North-West of Sana'a City, along the main road of Sana'a - Amran, between latitude 0408975 and 0409727 North and longitude between 1711737 and 1710719 East. It has a total area of $3 \mathrm{~km}^{2}$. It is located near fertile agriculture lands and residential areas. The construction and development of the study area, including its site selection, lacked the use of well-defined criteria. Several field visits to the study area were carried out in order to study the technical, socio-economic and institutional aspects.

Delineation and mapping of the different lithostratigraphic units and aquifer system and main structural elements at and around the study area site.

Establishing groundwater sampling stations, based on criteria defined by the objectives of this study. Twelve sampling stations have been established within $1 \mathrm{~km}$ distance from Al-Azraqin the study area (fig. 1). This distance has been determined according to the international standards in such cases. A review of literature (Hem [4], Handa [5], Helmer [6] and APHA [7]) provided guidelines for the sampling of groundwater. Following these guidelines, groundwater samples were collected in polyethylene containers of two liter capacity. The containers were washed with distilled water and dried before being used. They were labeled with number, location, depth, and date of collection, prior to the sampling. Groundwater samples were collected after the extraction of water from 
a hand pump. The water was left to run from the source for about half an hour to equate the minimum number of well volume and to stabilize the electrical conductivity (EC).

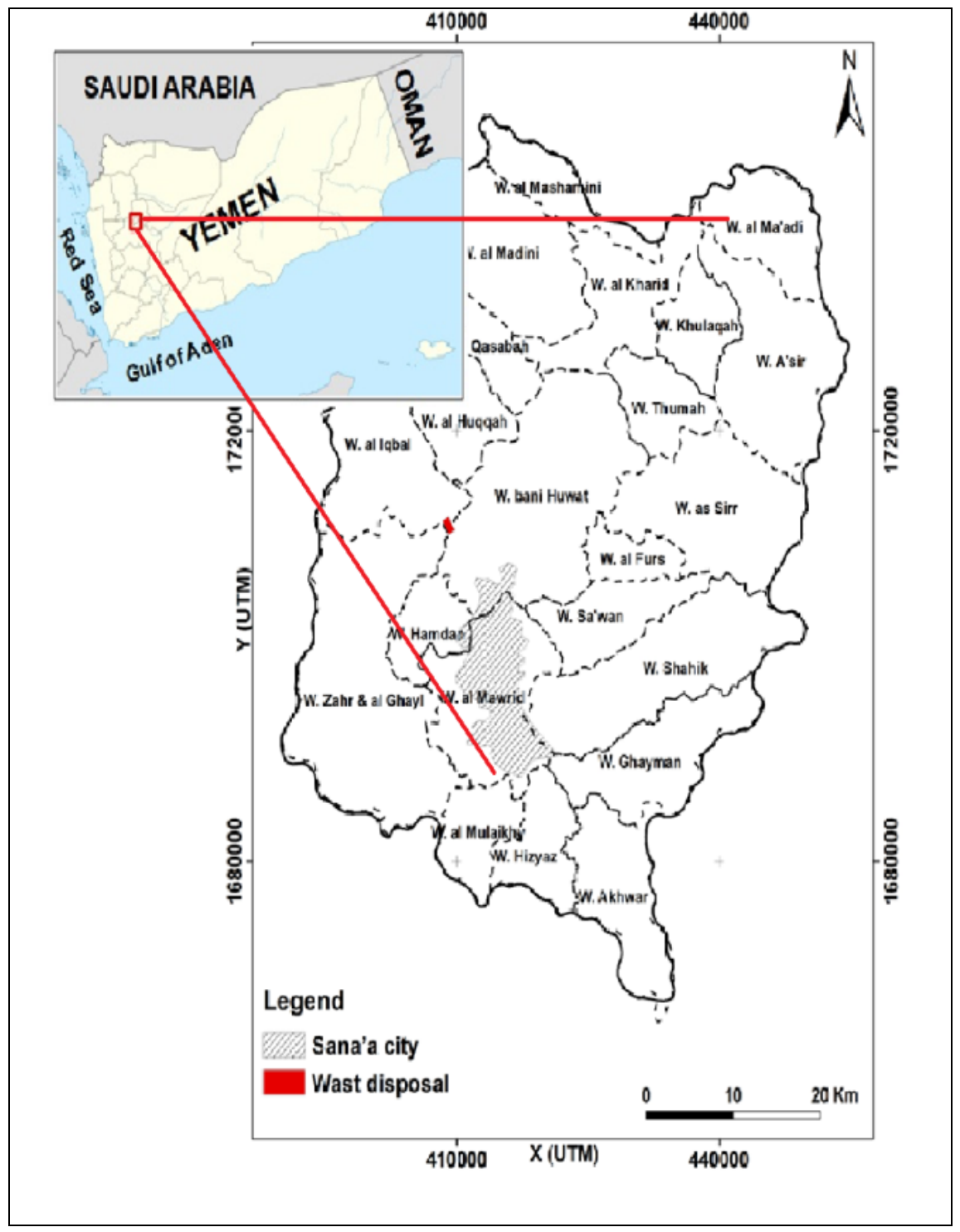

Figure 1: Location of the study area.

Twelve groundwater samples have been collected from the selected well stations. Details of the sampling points, aquifer types, depth and distance from Al-Azraqin are presented in table 1. 
Table 1: $\quad$ Information of groundwater sampling stations.

\begin{tabular}{|c|c|c|c|c|c|c|c|c|c|}
\hline \multirow{3}{*}{$\begin{array}{l}\text { Sr. No. } \\
\text { M-110 }\end{array}$} & \multicolumn{6}{|c|}{ Sampling locations } & \multirow{3}{*}{\begin{tabular}{|c|} 
Aquifer type \\
$\begin{array}{c}\text { Quaternary } \\
\text { basalt }\end{array}$ \\
\end{tabular}} & \multirow{3}{*}{$\begin{array}{c}\text { Depth of } \\
\text { pump in } \\
\text { meters }\end{array}$} & \multirow{3}{*}{$\begin{array}{c}\begin{array}{c}\text { Distance } \\
\text { from } \\
\text { landfill }\end{array} \\
\text { in meters } \\
10.7\end{array}$} \\
\hline & \multicolumn{3}{|c|}{ East (m) } & \multicolumn{3}{|c|}{ North (m) } & & & \\
\hline & 44 & 9 & 13.554 & 15 & 28 & 25.928 & & & \\
\hline M-111 & 44 & 9 & 35.638 & 15 & 29 & 6.66 & $\begin{array}{c}\text { Quaternary } \\
\text { Alluvial }\end{array}$ & 240 & 716 \\
\hline M-112 & 44 & 9 & 41.6 & 15 & 28 & 34.8 & $\begin{array}{c}\text { Quaternary } \\
\text { Alluvial } \\
\end{array}$ & 210 & 386 \\
\hline M-113 & 44 & 9 & 37.7 & 15 & 28 & 27.4 & $\begin{array}{c}\text { Quaternary } \\
\text { Alluvial }\end{array}$ & 200 & 211 \\
\hline M-114 & 44 & 8 & 56.2 & 15 & 28 & 24.8 & $\begin{array}{l}\text { Cretaceous } \\
\text { Sandstone } \\
\end{array}$ & 150 & 408 \\
\hline M-115 & 44 & 9 & 45.5 & 15 & 28 & 49.1 & $\begin{array}{c}\text { Quaternary } \\
\text { Alluvial }\end{array}$ & 210 & 705 \\
\hline M-116 & 44 & 9 & 4.9 & 15 & 28 & 3.36 & $\begin{array}{c}\text { Quaternary } \\
\text { Alluvial } \\
\end{array}$ & 300 & 693 \\
\hline M-117 & 44 & 9 & 9.42 & 15 & 28 & 15.06 & $\begin{array}{c}\text { Quaternary } \\
\text { Alluvial } \\
\end{array}$ & 240 & 529 \\
\hline M-118 & 44 & 9 & 38.8 & 15 & 28 & 51.6 & $\begin{array}{c}\text { Quaternary } \\
\text { Alluvial } \\
\end{array}$ & 210 & 352 \\
\hline M-119 & 44 & 9 & 43.9 & 15 & 28 & 52.9 & $\begin{array}{c}\text { Quaternary } \\
\text { Alluvial }\end{array}$ & 300 & 564 \\
\hline M-120 & 44 & 9 & 41.5 & 15 & 28 & 46.8 & $\begin{array}{c}\text { Quaternary } \\
\text { Alluvial } \\
\end{array}$ & 180 & 720 \\
\hline M-121 & 44 & 8 & 41.341 & 15 & 29 & 23.9 & $\begin{array}{c}\text { Quaternary } \\
\text { Alluvial }\end{array}$ & 210 & 560 \\
\hline
\end{tabular}

\subsection{Methods of study}

A review of literature on analytical procedures indicates that scientists from various organizations in different parts of the world have made substantial contributions in suggesting analytical procedures for water samples. The method used for these analyses were standardized according to standard methods of water and wastewater examination (WHO [2] and APHA [7]).

Twelve groundwater samples have been analyzed for physical, chemical, trace elements parameters. As has been mentioned earlier, some chemical, physical parameters were determined at the field such as: electrical conductivity 
(EC), $\mathrm{pH}$, temperature. Other parameters were determined at the laboratory such as: Calcium $\left(\mathrm{Ca}^{2+}\right)$, Magnesium $\left(\mathrm{Mg}^{2+}\right)$, Carbonate $\left(\mathrm{CO}_{3}{ }^{2-}\right)$, Bicarbonate $\left(\mathrm{HCO}_{3}{ }^{-}\right)$, Sodium $\left(\mathrm{Na}^{+}\right)$, Potassium $\left(\mathrm{K}^{+}\right)$, Chloride $\left(\mathrm{Cl}^{-}\right)$, Sulfate $\left(\mathrm{SO}_{4}{ }^{2-}\right)$, and Phosphate $\left(\mathrm{PO}_{4}^{3-}\right)$. Nine heavy metals i.e. Iron $\left(\mathrm{Fe}^{+}\right)$, Copper $\left(\mathrm{Cu}^{2+}\right)$, Zinc $\left(\mathrm{Zn}^{2+}\right)$, Lead $\left(\mathrm{Pb}^{2-}\right)$, Chromium $\left(\mathrm{Cr}^{6+}\right)$, Cadmium $\left(\mathrm{Cd}^{2+}\right)$, Nickel $\left(\mathrm{Ni}^{2+}\right)$, Manganese $\left(\mathrm{Mn}^{2+}\right)$ and Fluoride $\left(\mathrm{F}^{-}\right)$, were measured.

Twelve water samples from the well stations were subjected to chemical analysis. The total dissolved solids (TDS) were calculated by multiplying the measured EC values by 0.65 . The total alkalinity (T. Alk.) was measured by direct titration using $(0.02 \mathrm{~N})$ standard hydrochloric acid and phenolphthalein solution (ph.ph), or methyl orange solution (M.O) as indicators, and from the measurement and calculations we can get the values of Carbonate and Bicarbonate. The total hardness (TH) was measured by the EDTA Titrimetric Method, using a buffer solution of $\mathrm{NH}_{4} \mathrm{HCL}$ and $\mathrm{NH}_{4} \mathrm{OH}$, Eriochrome Black T (EBT) indicator, and standard EDTA $(0.01 \mathrm{M})$ as titrant. Magnesium was estimated as the difference between the total hardness as $\mathrm{mg} \mathrm{CO}_{3}{ }^{2-} / \mathrm{L}$ and calcium as $\mathrm{mg} \mathrm{CaCO}_{3} / \mathrm{L}$. The Argentometric Method was used to determine Chloride $\mathrm{Cl}^{-}$with using potassium chromate $\left(\mathrm{K}_{2} \mathrm{CrO}_{4}\right)$ indicator solution and $0.0141 \mathrm{~N}$ standard silver nitrate $\left(\mathrm{AgNO}_{3}\right)$. A Flame Photometer M7 DC DR LHNGE model was used to measure sodium $\mathrm{Na}^{+}$and potassium $\mathrm{K}^{+}$in the water samples. A Spectrophotometer HACH DR 4000 model was used to screen Sulphate $\mathrm{SO}_{4}{ }^{2-}, \mathrm{PO}_{4}{ }^{3-}$ and Iron $\mathrm{Fe}^{2+}$ directly, while the results of Nitrate $\mathrm{NO}_{3}{ }^{-}$ were shown in $\mathrm{mg} / \mathrm{L} \mathrm{NO}_{3}-\mathrm{N}$ (as nitrogen). Consequently the latter results were multiplied by 4.43 to get the concentration of $\mathrm{NO}_{3}^{-}$.

For trace element analysis samples were collected in polyethylene containers of two litter capacity. Concentrated $\mathrm{HNO}_{3}(69 \%)(5 \mathrm{ml})$ was added to the sample to imply that the relative proportions concentrations of all pertinent components will be the same in the samples will be handled in such a way that no significant changes in composition occur before the tests are made (APHA [7]).

Selected trace elements (fluoride, iron, cadmium, chromium, nickel, lead, manganese, copper and zinc) were analyzed by UV-Visible spectrophotometer following the standard procedures (APHA [7]). Cadmium and leads were determined using the Dithizone method. Chromium was analyzed at wavelength of $515 \mathrm{~nm}$ by using 1,5-Diphenylcarbohydrazide method. Fluoride content was estimated by colorimetric method using SPADNS at $580 \mathrm{~nm}$ wavelength. The Bicinchoninate method was used to analyze copper at a wavelength of $560 \mathrm{~nm}$. Manganese content was analyzed by using 1-(2-Pyridylazo)-2-Naphthol PAN Method at a wavelength of $560 \mathrm{~nm}$. Nickel was estimated at $430 \mathrm{~nm}$ using the Heptoxime method. Iron content was analyzed using the Ferrover ${ }^{\circledR}$ Method at wavelength $510 \mathrm{~nm}$, while the Zincon method was used to determine zinc at $620 \mathrm{~nm}$. 


\section{Results}

The assessment of the physico-chemical quality of the water Al-Azraqin, located in the North-West of Sana'a city, is done by analysis of water collected at 12 drilling sites during the period 2010.

\subsection{PH}

$\mathrm{PH}$ of the solution is expressed as the negative logarithm to the base 10 of the hydrogen ion activity in moles per liter (Henry and Heinke [8]). It indicates the balance between acids and bases in the water. Low $\mathrm{pH}$ of water imparts characteristic acidic taste while high $\mathrm{pH}$ gives the water a bitter taste. The $\mathrm{pH}$ of most groundwater is to a great extent influenced by the balance between dissolved carbon dioxide gas derived from the atmosphere and the biological activity, and the dissolved carbonates/bicarbonates derived from carbonate rocks. The minimum and maximum $\mathrm{pH}$ values (7.24 and 8.02) are recorded for the samples M-113 and M-121, respectively.

\subsection{Electric conductivity and TDS}

The minimum and maximum EC value $(522$ and $687 \mu \mathrm{s} / \mathrm{cm})$ are recorded for the samples M-113 and M-121 respectively, and was found to be within the permissible limits of the Yemen standards and WHO Guidelines.

According to the standard limits of $1000 \mathrm{mg} / \mathrm{l}$ for TDS all the analyzed samples were within the limit. According to Ongreths water classification for TDS, the entire analyzed samples are considered to be good (between 300 $600 \mathrm{mg} / \mathrm{l})$. The minimum and maximum TDS values (339 and $447 \mathrm{mg} / \mathrm{l}$ ) is recorded for the samples M-121 and M-113, respectively.

\subsection{Hardness}

The values of total hardness as $\mathrm{CO}_{3}{ }^{2-}$ for the analyzed samples ranged between 186 to $252 \mathrm{mg} / \mathrm{l}$ which corresponds with Yemen standard and WHO Guidelines limits of $500 \mathrm{mg} / \mathrm{l}$. According to the degree of drinking water hardness classification, all samples are considered hard (because their values fall in the range between 150-300 mg/l. According to WHO Guidelines (WHO [9]) the hard water with hardness above approximately $200 \mathrm{mg} / \mathrm{l}$ will result in excessive soap consumption and subsequent "scum" formation. The differences in hardness of the analyzed samples may be attributed to the type of aquifer lithology.

\subsection{Ions and trace metals (table 2)}

The concentrations of $\mathrm{Mg}^{2+}$ for the analyzed samples were found within WHO and Yemen standard limits. The minimum and maximum $\mathrm{Mg}^{2+}$ values ( 9 and $25 \mathrm{mg} / \mathrm{l}$ ) are recorded for the samples M-112 and M-119 respectively. 
The concentrations of $\mathrm{Ca}^{2+}$ for the analyzed samples, indicates that the minimum and maximum $\mathrm{Ca}^{2+}$ values $(47$ and $68 \mathrm{mg} / \mathrm{l}$ ) are recorded for the samples M-121, M-111 and M-120 respectively, and were found within WHO and Yemen standard limits.

The minimum and maximum $\mathrm{Na}^{+}$values $(27$ and $63 \mathrm{mg} / \mathrm{l})$ are recorded for the samples M-111, M-118 and M-112, M-113 respectively. According to the US EPA advisory limits, these values are considered high, but according to the WHO of $200 \mathrm{mg} / \mathrm{l}$, and Yemeni Standard of $400 \mathrm{mg} / \mathrm{l}$, they are within the acceptable limits.

According to Yemen Standards of $12 \mathrm{mg} / \mathrm{l}$ for $\mathrm{K}^{+}$, all the values were within the permissible limits. The minimum and maximum $\mathrm{K}^{+}$values (1.03 and $3.15 \mathrm{mg} / \mathrm{l}$ ) is recorded for the samples $\mathrm{M}-112$ and $\mathrm{M}-121$ respectively.

The average abundance of Copper in groundwater is less than $0.1 \mathrm{mg} / \mathrm{l}$. The analyzed data of copper is incorporated in table 2 . It indicates that the minimum and maximum values $(0.01$ and $0.15 \mathrm{mg} / \mathrm{l})$ are recorded for the samples (M-117 and M-111).

According to the average abundance of $\mathrm{Cu}$, only one sample was found to contain a little bit $\mathrm{Cu}$ more than the natural content in the groundwater. On the other hand, according to WHO Guidelines limit of $1-2 \mathrm{mg} / \mathrm{L}$ and to Yemen standard limit of 0.5 to $1 \mathrm{mg} / \mathrm{l}$, all analyzed samples were found to be within the limits.

Table 2: $\quad$ Trace elements data for the water samples in $\mathrm{mg} / \mathrm{l}$.

\begin{tabular}{|l|l|l|l|l|l|l|l|l|l|}
\hline Sr. No. & \multicolumn{1}{|c|}{ Cd } & \multicolumn{1}{|c|}{$\mathbf{C r}$} & $\mathbf{C u}$ & $\mathbf{F}$ & $\mathbf{F e}$ & $\mathbf{P b}$ & $\mathbf{N i}$ & $\mathbf{M n}$ & $\mathbf{Z n}$ \\
\hline WHO & 0.003 & 0.05 & $1-2$ & $0.5-1.5$ & 0.3 & 0.01 & 0.02 & $0.1-0.5$ & 3.0 \\
\hline Yemen & 0.005 & 0.05 & $0.5-1$ & $0.5-1.5$ & 0.3 & 0.05 & 0.01 & $0.1-0.2$ & 5.0 \\
\hline M-110 & 0.0021 & 0.024 & 0.04 & 0.68 & 0.06 & 0.002 & 0.01 & 0.022 & 0.13 \\
\hline M-111 & 0.0014 & 0.069 & 0.15 & 0.06 & 0.11 & 0.007 & 0.03 & 0.006 & 0.09 \\
\hline M-112 & 0.0013 & 0.055 & 0.06 & 1.98 & 0.50 & 0.010 & 0.02 & 0.116 & 0.05 \\
\hline M-113 & 0.0054 & 0.037 & 0.08 & 1.66 & 0.20 & 0.014 & 0.03 & 0.190 & 0.07 \\
\hline M-114 & 0.0021 & 0.031 & 0.05 & 0.88 & 0.04 & 0.010 & 0.01 & 0.023 & 0.08 \\
\hline M-115 & 0.0010 & 0.080 & 0.07 & 0.74 & 0.49 & 0.018 & 0.01 & 0.144 & 0.06 \\
\hline M-116 & 0.0013 & 0.017 & 0.04 & 1.44 & 0.26 & 0.013 & 0.02 & 0.050 & 0.13 \\
\hline M-117 & 0.0018 & 0.026 & 0.01 & 1.15 & 0.18 & 0.005 & 0.01 & 0.050 & 0.13 \\
\hline M-118 & 0.0010 & 0.013 & 0.09 & 0.54 & 0.05 & 0.014 & 0.03 & 0.097 & 0.12 \\
\hline M-119 & 0.0020 & 0.015 & 0.05 & 0.18 & 0.22 & 0.011 & 0.02 & 0.033 & 0.17 \\
\hline M-120 & 0.0010 & 0.021 & 0.08 & 0.15 & 0.03 & 0.012 & 0.01 & 0.06 & 0.12 \\
\hline M-121 & 0.0015 & 0.042 & 0.04 & 0.41 & 0.01 & 0.007 & 0.02 & 0.009 & 0.14 \\
\hline
\end{tabular}

The data of chromium content for the 12 groundwater samples is incorporated in table 2 . The minimum and maximum values $(0.01$ and $0.08 \mathrm{mg} / \mathrm{l})$ are recorded for the samples (M-118 and M-115) respectively. It has been found also that only 3 samples (M-111, M-112, and M-115) are having values above the permissible limits. The polluted samples are collected from wells located towards Northeast of the landfill. Chromium is considered nonessential for plants, but an essential 
trace element for animals. FAO and the U.S EPA primary drinking water standard recommended maximum level of chromium in irrigation waters and drinking water should not exceed $0.1 \mathrm{mg} / \mathrm{l}$.

Table 3: $\quad$ Physico-chemical data for the water samples in $\mathrm{mg} / \mathrm{l}$.

\begin{tabular}{|c|c|c|c|c|c|c|c|c|c|c|}
\hline $\begin{array}{c}\text { Series } \\
\text { No. }\end{array}$ & $\mathrm{TDS}$ & $\mathrm{Ca}$ & $\mathrm{Mg}$ & $\mathrm{Na}$ & $\mathrm{K}$ & $\mathrm{HCO}_{3}$ & $\mathrm{Cl}$ & $\mathrm{SO}_{4}$ & $\mathrm{NO}_{3}$ & $\mathrm{PO}_{4}$ \\
\hline WHO & 1000 & 200 & ----- & 200 & ---- & ----- & 250 & 400 & 50 & ----- \\
\hline Yemen & 1500 & 200 & $30-150$ & 400 & 12 & 500 & 600 & 400 & 50 & ----- \\
\hline $\mathrm{M}-110$ & 381 & 52 & 19 & 30 & 3 & 205 & 28 & 63 & 6.3 & 0.211 \\
\hline $\mathrm{M}-111$ & 377 & 68 & 18 & 27 & 1.13 & 288 & 27.5 & 40 & 5.3 & 0.134 \\
\hline $\mathrm{M}-112$ & 395 & 61 & 9 & 63 & 1.03 & 256 & 28 & 65 & 7.04 & 0.52 \\
\hline $\mathrm{M}-113$ & 447 & 63 & 14 & 63 & 1.22 & 254 & 30 & 105 & 5.7 & 0.32 \\
\hline $\mathrm{M}-114$ & 423 & 64 & 15 & 52 & 2.13 & 237 & 19 & 115 & 6.2 & 0.08 \\
\hline $\mathrm{M}-115$ & 389 & 59 & 12 & 54 & 1.81 & 279 & 36 & 37 & 7 & 0.35 \\
\hline $\mathrm{M}-116$ & 438 & 60 & 15 & 44 & 2.47 & 217 & 29 & 100 & 6.3 & 0.12 \\
\hline $\mathrm{M}-117$ & 417 & 59 & 16 & 40 & 2.46 & 223 & 28 & 92 & 7 & 0.18 \\
\hline $\mathrm{M}-118$ & 397 & 54 & 24 & 27 & 2.73 & 254 & 27 & 58 & 7 & 0.32 \\
\hline $\mathrm{M}-119$ & 411 & 59 & 25 & 31 & 2.35 & 288 & 27 & 69 & 8.4 & 0.11 \\
\hline $\mathrm{M}-120$ & 402 & 68 & 17 & 43 & 2.11 & 281 & 36 & 55 & 7 & 0.05 \\
\hline $\mathrm{M}-121$ & 339 & 47 & 17 & 32 & 3.15 & 211 & 23 & 53 & 13 & 0.01 \\
\hline
\end{tabular}

The cadmium content in the analyzed samples ranged between 0.001 to $0.0054 \mathrm{mg} / \mathrm{l}$. The minimum and maximum values $(0.0010$ and $0.0054 \mathrm{mg} / \mathrm{l})$ are recorded for the samples (M-113, M-115, M-118 and M-120). According to WHO Guidelines limit (0.003) and Yemen standard limit $(0.005 \mathrm{mg} / \mathrm{l})$ for cadmium, it was found that 11 samples were within the limits, and only one sample (M-113) was polluted by cadmium. According to APHA [7], the average abundance of Cadmium in groundwaters ranges from 0.007 to $0.01 \mathrm{mg} / \mathrm{l}$.

The minimum and maximum $\mathrm{Cl}^{-}$values (19 and $36 \mathrm{mg} / \mathrm{l}$ ) is recorded for the samples M-114 and M-115, M-120 respectively. The sulfate content is found within the WHO Guidelines and Yemen Standards limits of $400 \mathrm{mg} / 1$ for $\mathrm{SO}_{4}{ }^{2-}$.

The minimum and maximum $\mathrm{SO}_{4}{ }^{2-}$ values $(37$ and $115 \mathrm{mg} / \mathrm{l})$ is recorded for the samples $\mathrm{M}-115$ and $\mathrm{M}-114$ respectively.

The nitrate content is found within the acceptable limits of $50 \mathrm{mg} / \mathrm{l}$. The maximum and minimum $\mathrm{NO}_{3}{ }^{-}$values $(5.3$ and $13 \mathrm{mg} / \mathrm{l})$ are recorded for the samples $\mathrm{M}-111$ and $\mathrm{M}-121$ respectively.

The concentrations of $\mathrm{PO}_{4}{ }^{3-}$ indicates that the minimum and maximum values $(0.01$ and $0.35 \mathrm{mg} / \mathrm{l})$ are recorded for the samples M-121 and M-115.

The minimum and maximum values of fluoride $(0.06$ and $1.98 \mathrm{mg} / \mathrm{l})$ are recorded in samples (M-111 and M-112). According to WHO Guidelines and Yemen standard the limits of fluoride are $(0.5-1.5 \mathrm{mg} / \mathrm{l})$. In view of that, it has been found that only two samples (M-112, M-113) have been reported polluted by $\mathrm{F}^{-}$, while one sample (M-116) has the recommended level.

The Iron contents have been incorporated in table 2. It indicates that minimum and maximum values of Iron recorded in samples are (0.01 and 
$0.50 \mathrm{mg} / \mathrm{l})$. According to WHO Guidelines and Yemen standard, the permissible limit of Iron is $0.3 \mathrm{mg} / \mathrm{l}$. In view of that, it has been found that only 2 groundwater samples (M-112 and M-115) were polluted with Iron, while only one sample has the maximum acceptable value of Iron (M-116).

The lead concentrations of the analyzed samples have been incorporated in table 2. It Shows the minimum and maximum values $(0.002$ and $0.018 \mathrm{mg} / \mathrm{l})$, which have been recorded in samples (M-110 and M-115). According to WHO Guidelines limit of $0.01 \mathrm{mg} / \mathrm{l}$, it was found that 7 samples out of 12 had slightly higher $\mathrm{Pb}$ concentrations than the WHO limit for $\mathrm{Pb}$, while 2 samples had the recommended maximum level of $\mathrm{Pb}$. However, according to the Yemen standard limits of $0.05 \mathrm{mg} / \mathrm{l}$ for $\mathrm{Pb}$, all samples were within these limits. On the other hand it was noticed that all $\mathrm{Pb}$ values obtained were still less than the average abundance of $\mathrm{Pb}$ in groundwater. That means, the groundwater pollution with $\mathrm{Pb}$ could occur as a result of the leachates or natural pollution.

Nickel concentrations of the studied samples have been incorporated in table 2. It shows the minimum and maximum values $(0.01$ and $0.03 \mathrm{mg} / \mathrm{l})$ which have been recorded on samples (M-110, M-114, M-115, M-117, M-120 and M-111, M-113, M-118) respectively. According to WHO Guidelines limits of 0.02, it was found that 4 out of these 12 analyzed samples had the recommended maximum level of $\mathrm{Ni}$ and 3 samples had higher concentrations than the limits, but according to Yemen standard limits of $0.02 \mathrm{mg} / \mathrm{l}$ for $\mathrm{Ni}$, it was found that 5 samples had the recommended maximum level of $\mathrm{Ni}$ whereas 7 samples had higher concentrations than the limits.

The concentrations of manganese in the studied samples have been incorporated in table 2 . It shows the minimum and maximum values $(0.006$ and $0.190 \mathrm{mg} / \mathrm{l})$ which have been recorded on samples (M-111 and M-113) respectively. According to WHO Guidelines limits of $0.01-0.05 \mathrm{mg} / \mathrm{l}$; and Yemen standard limits of $0.01-0.02 \mathrm{mg} / 1$ for manganese, it was found that 4 samples exceeded the recommended minimum level of $\mathrm{Mn}$, and one of these four samples had the recommended maximum level of Mn according to the Yemen standard.

The results of zinc concentrations have been incorporated in table 2. It show the minimum and maximum values $(0.05$ and $0.17 \mathrm{mg} / \mathrm{l})$ which have been recorded on samples (M-112 and M-119) respectively.

\section{Discussion and conclusion}

Al-Azraqain is the only area allocated for solid disposal of Sana'a City. The study area receives waste from Sana'a City, Sana'a Governorate and Amran Governorate. The waste dumped at this site includes domestic wastes, construction and demolition wastes, and waste from adjacent poultry, fish market, slaughter houses and non infectious hospitals. Medical and industrial wastes have no units for primary treatment or sanitary landfills. Furthermore, hazardous and non-hazardous waste disposed without applying any special methods for handling and sorting. 
Al-Azraqin was not selected on scientific bases, and no environmental impact assessment has been carried out prior to selection of this site. This site is located on an area characterized by geological structure and vulnerable aquifers, which forms a major problem that may cause water quality deterioration.

From the above results, it is found that the values of the physico-chemical parameters of the analyzed samples were within the limits of WHO Guidelines and Yemen standards. Due to lack of previous groundwater quality data for the period before the construction of the landfill it is difficult to judge whether the present physiochemical values were the same for these well many years ago. Hence, this does not mean that there is no impact of the landfill on water quality.

Twelve groundwater samples have been analyzed for Cadmium, Chromium, Fluoride, Iron, Lead, Nickel and Manganese. The obtained data compared to the data with WHO drinking water standards WHO [2] revealed that some of the samples were polluted with $\mathrm{Cd}, \mathrm{Cr}, \mathrm{F}, \mathrm{Fe}, \mathrm{Pb}, \mathrm{Ni}, \mathrm{Mn}$ and $\mathrm{Zn}$.

Has been constructed using Arc GIS software to assess the concentration and distribution of Cadmium, chromium, fluoride, Iron, Lead values in and around the landfill. The distribution of Cadmium is controlled by the general groundwater flow trends i.e. from south-west to north east. The source of fluoride can be attributed to the volcanic rock present in the area. $\mathrm{F}^{-}$at low concentration $\sim 1 \mathrm{mg} / \mathrm{l}$ in drinking water has been considered beneficial but high concentrations may cause dental fluorosis (tooth mottling) and more seriously skeletal flourosis (APHA [7]).

It has been found that the maximum concentrations of Nickel are located to the east and north of the landfill. This indicates that the groundwater water flow which has northeast direction plays an important role in the concentration mechanism. It is clear that maximum Mn concentration has been recorded at well (M-113) that located to the east of the landfill site. This indicates that the groundwater water flow (north-east) plays an important role in concentration and migration of the Manganese.

The WHO Guidelines limit of $3.0 \mathrm{mg} / \mathrm{l}$ and Yemen standard of $5.0 \mathrm{mg} / \mathrm{l}$. On the other hand, according to Ravindra and Garg [10] the average abundance of $\mathrm{Zn}$ in groundwater is less than $0.1 \mathrm{mg} / \mathrm{l}$, hence only out of the analyzed samples 7 samples were slightly higher than the natural rate of $\mathrm{Zn}$ abundance in the groundwater. Zinc is used in a number of alloys such as brass and bronze, batteries, fungicides, and pigments, therefore the higher values of $\mathrm{Zn}$ could be as a result of the leachate of the study area.

The quality of ground water depends upon several factors such as chemical composition of the aquifers - climatic conditions prevailing during formation and quantum of water available in the aquifer and its rate of circulation. Apart from these, activities of micro-organisms, temperature and pressure are responsible for the chemical characteristics of groundwater (Ibiyemi [11]). Thus, it can be concluded that the leachates arising from the landfill site is responsible for the acidic level of the sample wells. In the study, we have been able to see that landfilling activities impact negatively on not only groundwater quality (Iwugo [12]). We have found such a study in Nigeria, the impact of solid waste on groundwater by the researcher Aderemi et al. [13]. The presence of $\mathrm{Pb}$ and $\mathrm{Cd}$ 
in the landfill leachate and their absence in all the groundwater samples can be attributed to the sub-surface geology of the site which consists of clay. These metals have the affinity to be absorbed by clayey soil (Mor et al. [14] and Enekwechi [15]). Also we have found such a study in India, the impact of solid waste on groundwater by the researchers Umesh et al. [16].

The population in Sana'a City depends on the groundwater as the main source for getting water. Groundwater quality was discussed with respect to technical, social, institutional and environmental aspects because water quality is an important component of Integrated Water Resources Management IWRM.

The physico-chemical analysis showed that the selected major ions of the analyzed samples were within the limits of WHO Guidelines and Yemen Standard. However, this does not assure that there is not any impact of the AlAzraqin on the ambient groundwater quality. Although no water pollution is indicated from the obtained analytical results, it could not be concluded that AlAzraqin has no impacts on the water quality degradation. Lack of previous data or water quality analysis for the boreholes around the Al-Azraqin, it is to make a comparison in order to figure out the role of Al-Azraqin in changing the groundwater quality. Accordingly, this study could be a base study for future investigations on groundwater quality of this site.

\section{References}

[1] Noaman, A. Personal communication, 2008. Adapting to water scarcity for Yemen's vulnerability communities, case study, Sana'a city. Yemen.

[2] World Health Organization (WHO), (eds). Guideline for Drinking Water Quality, Health Criteria and Other Supporting Information: 2nd Edition, Vol.2, Geneva, pp. 940-949, 2004.

[3] ESCWA. Presentations of the Expert Group Meeting on the Application of Indicators and the Indices for Water Quality Management in the ESCWA Region, Sana, Yemen. 06-2007.

[4] Hem, J. D., Study and interpretation of the chemical characteristics of natural waters, U.S. Geol. Sur. Water Supply Paper, 2nd Ed., no. 1473, $363 p$ (1970).

[5] Handa, B.K., Saline water resources in India, Technical manual, Central Groundwater Board, Ministry of Agricultural and Irrigation, 317p (1979).

[6] Helmer, R. C., Water quality monitoring: A global approach. Nature and Resources, 18(1), pp. 7-13, 1981.

[7] APHA, Standard methods for examination of water - wastewater. $17^{\text {th }}$ Ed. American Public Health Association, Washington, 1500p, 1989.

[8] Henry, J.G., Heinke, G. W., Environmental Science and engineering, Prentice Hall, Englewood Cliffs, NJ (1989).

[9] WHO Guidelines for drinking water quality, V.1,2, Geneva, 335 p (1984).

[10] Ravindra, K. and Garg, V. K., Distribution of fluoride in groundwater and its suitability assessment for drinking purpose. Int. J. Environ. Health Res. $16,1-4,2006$. 
[11] Ibiyemi, A. O., (2000). Evaluating validity of contingent valuation model for household Willingness-to-Accept near Olusosun Waste Disposal Site, Lagos. www.abayomiibiyemi.nl/.

[12] Iwugo, K. O., Groundwater Quality Treatment and Pollution in Nigeria. The Lagos Metropolis Case Study. First Annual Symposium on Groundwater Resources: Water and Sanitation Association, Lagos, Nigeria, 1986.

[13] Aderemi, A. O., Oriaku, A. V., Adewumi G. A. and Otitoloju A. A., Assessment of groundwater contamination by leachate near a municipal solid waste landfill, 2011.

[14] Mor, S., Ravindra, K., Dahiya, R.P., Chandra, A., Leachate characterization and assessment of groundwater pollution near municipal solid waste landfill site. Environ. Monit. Assess. 4, pp. 325-334, 2006.

[15] Enekwechi, L.O., Investigation on potential groundwater impacts and influence of local hydrogeology on natural attenuation of leachate at a municipal landfill. Int. J. Environ. Sci. Technol., 4(1), pp. 133-140, 2007.

[16] Umesh, K.S., Manish K., Chauhan R., Pawan K. Jha, Ramanathan, A.L. and Subramanian V. Assessment of the impact of landfill on groundwater quality: A case study of the Pirana site in western India. 